\title{
Educator Readiness Evaluation in the Implementation of Curriculum 2013 in Disadvantaged, Frontier, and Outermost Areas
}

\author{
Hendra Saputra S. Adiko ${ }^{1}$, Rusli Abdurahman Idji ${ }^{2}$ \\ hendra.adikoumg@gmail.com \\ ${ }^{1}$ Faculty of Teacher Training and Education, Muhammadiyah University of Gorontalo, Indonesia \\ ${ }^{2}$ Faculty of Economics and Social Sciences, Muhammadiyah University of Gorontalo, Indonesia \\ Received: November 23, 2020 \\ Revised: December 5, 2020 \\ Accepted: December 21, 2020
}

\begin{abstract}
This study aims to describe the readiness of educators in implementing the 2013 curriculum in the $3 \mathrm{~T}$ area in North Gorontalo District. The method used in this research is descriptive qualitative method. The subjects in this study were school principals and educators in the 3T area school. The research result shows four things; first; Academic qualifications of educators in schools in the 3Tl area have not been fully fulfilled according to Law No. 20 of 2003 concerning the National Education System Article 42 paragraph (1). Second; The Academic Competence of Educators in the $3 \mathrm{~T}$ area is not yet fully educated with $\mathrm{S} 1$ academic qualifications in accordance with Article 8 of Law Number 14 of 2005. The three certificates of educators have not been fully fulfilled in accordance with the mandate of Law Number 14 of 2005 concerning Educators and Lecturers. The fourth role of educators in realizing the goals of national education principals continues to encourage educators to continue to carry out learning innovations, especially in the implementation of the 2013 curriculum as an effort to improve professionalism as a form of role in realizing the goals of national education.
\end{abstract}

Keywords: Education, Educator Readiness, Curriculum

\section{Introduction}

Education is a conscious effort to humanize humans, where currently the task of an educator is not only as a teacher but also as an educator. Education is one thing that is very important and a necessity for all society. In general, education is a learning process that includes knowledge, skills, and habits carried out by a group of people or a group of humans who are passed down from one generation to the next through teaching, research, and training (Biesta, 2009; National Research Council, 2012). An educator is expected to be able to carry out educational functions and to achieve educational goals. An educator is a human being who is consciously able to influence others with the aim of transferring knowledge (Darling-Hammond \& Bransford, 2007; Lucas et al., 2008). The role of educators in making knowledgeable students is very important so that the quality of educators is very concerned for the creation of the expected students.

The issue of equitable education can be understood by the condition of the school-age population in 3T areas, namely the Frontier, Remote and Disadvantaged areas. Some of the problems in the implementation of education in these areas include a lack of supply of teaching staff, unbalanced distribution, low incentives, substandard qualifications, less competent educators, and mismatch 
between educational qualifications and the field being pursued, the implementation of the curriculum in schools has not according to standardized mechanisms and processes.

The curriculum is a set of subjects and educational programs provided by an education provider which contains lesson plans that will be given to participants in a period of education (Armor \& Duncombe, 2004; Lee et al., 2007). Changes or changes to the curriculum were made in order to adapt to the times and the old curriculum was deemed no longer appropriate to the conditions and needs of the times besides that, to fix the shortcomings of the old curriculum with the new curriculum. However, the change itself must be accompanied by sufficiently mature preparation such as preparing teachers to implement the curriculum itself so that the implementation of the new curriculum can run effectively and efficiently. The preparation of these subject instruments is adjusted to the circumstances and abilities of each level of education in the provision of this education as well as the needs of the work field.

The length of time in a curriculum is usually adjusted to the aims and objectives of the education system being implemented (Soukup et al., 2007; Barnett et al., 2008). In Lie's (2004) curriculum theory the success of a curriculum is a long process, starting from the crystallization of various ideas and ideal concepts about education, formulating curriculum design, preparation of educators and education personnel, as well as facilities and infrastructure, governance of curriculum implementation, among them: Learning Planning, Implementation Learning, Learning Evaluation, to Inhibiting and Supporting Factors for Learning Implementation.

In an era that is all modern where learning is easy to do with various existing media, making educators as educators must be able to provide educational services to students according to their needs and times. The low level of public recognition of the teaching profession is due to several factors, including: (1) There is an opinion on the part of the community, that anyone can become an educator as long as he/she is knowledgeable; (2) shortage of educators in remote areas, providing opportunities to appoint someone without expertise to become educators / educators; (3) many educators do not appreciate their profession, let alone try to develop that profession. Feelings of inferiority due to being an educator, abuse of the profession for personal satisfaction and interests so that the teacher's prestige is decreasing, and (4) weaknesses that exist in the educator himself, including low levels of competence which are still below standard. That way educators must have the ability to manage learning, the ability to provide good role models, the ability to be professional educators, and the ability to communicate and interact.

\section{Methods}

This research uses descriptive research with a qualitative approach, descriptive research is based on the consideration that the data is obtained more fully, in depth and reliably and that events in the social context can be found. The location of this research is at 3T area elementary school in North Gorontalo District. Qualitatively, it aims to find out or describe the reality of the events under study so that it makes it easier for the author to obtain objective data in order to know and understand the readiness of educators in implementing the 2013 curriculum in 3T primary schools in North Gorontalo District. The technique of collecting data from this research is observation, namely by observing directly by noting the symptoms found in the field. interview, namely asking questions directly to the principal, educators as parties who have relevance to research. As well as informal conversations are all sources of qualitative data. 


\section{Results and Discussion}

\section{Academic Qualifications}

In Law No. 20 of 2003 concerning the National Education System Article 42 paragraph (1) "Educators must have minimum qualifications and certification in accordance with the level of teaching authority, are physically and mentally healthy, and have the ability to realize the goals of national education." In this article it is very clear that Educators in Indonesia must have the minimum qualifications and must take certification to improve the academic qualifications and competence of Educators. From the results of interviews with school principals in the two schools that were the research samples in 3T schools, researchers can conclude that the academic qualifications of educators in remote schools have not been fully fulfilled. one of the schools whose educators are qualified under S1 Non Education.

\section{Educator Academic Competence}

Based on Law Number 14 of 2005 concerning Educators and Lecturers, Article 10 paragraph (1) states that "Educator competence as referred to in Article 8 includes pedagogical competence, personality competence, social competence, and professional competence obtained through professional education". Educator competency standards include the core competencies of Educators which are developed into competences of Elementary School Educators, and Subject Educators at Primary Schools.

The results of interviews conducted by researchers with school principals at the target school can conclude that the Educator Competence as referred to in Article 8 of Law Number 14 of 2005 includes pedagogical competence, personality competence, social competence, and professional competence, concluding that in general, Educators So far, the method used is conventional, tends to be verbal, meaning that all activities in the teaching and learning process are only centered on the Educator so that it seems that Educators are more active than students, then the teaching ability of Educators has not fully developed properly from the results of the interviews. The reason is that educators have not fully had $\mathrm{S} 1$ academic qualifications so they do not yet know the basic competency standards that an educator must have, and the second factor is that if the Educators already have the basic competence of an educator, the ability jar and the ability to innovate learning is hampered by the lack of supporting facilities for learning activities plus the ratio between educators and students is not balanced so that educators seem less motivated in terms of making innovations in the learning process in the classroom.

\section{Educator Certificate}

In accordance with the mandate of Law number 14 of 2015 regarding the Law on Educators and lecturers, that everyone who will teach at least is a bachelor's degree graduate and has a certificate of teaching staff. In other words, people who do not have these two things cannot be appointed as teachers or educators. From the results of the Educator interview, the researcher can state that, the competence of educators includes pedagogical competence, personality competence, social competence, and professional competence obtained through professional education, in accordance with the mandate of Law Number 14 of 2005 concerning Educators and Lecturers, not yet fully understood. This is because there are still schools whose Human Resources, in this case educators, are still far from the standard of academic competence of an educator. Where the competence of educators is a combination of personal, scientific, technological, social, and spiritual abilities that comprehensively form the standard competencies 
of the teaching profession, which includes mastery of material, understanding of students, educational learning, personal development, and professionalism. The academic competence of educators referred to above is one of the minimum educational qualifications of S1 which must be met by an educator as evidenced by a relevant diploma or certificate of expertise in accordance with the provisions of the applicable legislation.

The ability of educators to realize the goals of national education in the implementation of the 2013 curriculum in 3T regional elementary schools

As professional educators do have a role in realizing the goals of national education. The aim of National Education is to develop the potential of students to become human beings who believe and fear God Almighty, have noble character, are healthy, knowledgeable, capable, creative, independent and become democratic and responsible citizens. Educators' understanding of the 2013 curriculum can show how much readiness of educators is in implementing the 2013 curriculum, especially in the 3T Kasawan.

Educators' understanding of the 2013 curriculum can show how much readiness of educators is in implementing the 2013 curriculum, especially in the 3T Kasawan. The concept of "educator readiness" is a phrase consisting of two words, namely "readiness" and "educator". The word readiness comes from the word ready, which means the attitude or condition "is ready" (KBBI, 2005). The definition of educators is formally stated in Law no. 14 of 2005 is defined as, "professional educators with the main task of educating, teaching, guiding, directing, training, assessing, and evaluating students in early childhood education through formal education, basic education, and secondary education.

From the results of interviews between school principals and researchers, it can be concluded that the ability of educators to realize the goals of national education in the implementation of the 2013 curriculum in elementary schools in the 3T area. In the context of implementing the 2013 curriculum, educators as the forefront of the development and implementation of learning at the school level, should understand this position in the K-13 structure. Furthermore, educators also have the responsibility and obligation to make fundamental efforts in various forms of innovation learning so that the implementation of the learning process can achieve the specified competencies. Effective implementation is the result of the interaction between implementation strategies, curriculum structure, educational goals, and principal leadership. The results of research in 3T area primary schools show that so far the principal has continued to encourage educators to continue to carry out learning innovations, especially in implementing the 2013 curriculum as an effort to improve professionalism as a form of role in realizing the goals of national education. Learning innovation is something that is important and must be owned or done by teachers. This is because learning will be more lively and meaningful. Innovative learning is learning designed by teachers, which is new, not as is usually done (Pintó, 2005; Motteram, 2013; Manoe, 2020). Learning that pays attention to the auditory, visual, and kinesthetic dimensions so that the message given will be stronger. The willingness of the teacher to try to find, explore and look for various breakthroughs, approaches, methods and learning strategies is one of the supports that will attract a learning process for students.

\section{Conclusion}

Academic qualifications for educators in remote schools have not been fully fulfilled according to Law no. 20 of 2003 concerning the National Education System Article 42 paragraph (1). Then the Academic competence of Educators in the $3 \mathrm{~T}$ area is not yet fully educated. 
Educators have S1 academic qualifications in accordance with Article 8 of Law Number 14 of 2005. Furthermore, the certificate of educators has not been fully fulfilled in accordance with the mandate of Law Number 14 of 2005 concerning Educators and Lecturers and the Role of Educators To realize the goals of national education, the principal continues to encourage educators to continue to carry out learning innovations, especially in the implementation of the 2013 curriculum as an effort to improve their professionalism as a form of role in realizing the goals of national education.

\section{References}

Armour, K. M., \& Duncombe, R. (2004). Teachers' continuing professional development in primary physical education: Lessons from present and past to inform the future. Physical education \& sport pedagogy, 9(1), 3-21.

Barnett, W. S., Jung, K., Yarosz, D. J., Thomas, J., Hornbeck, A., Stechuk, R., \& Burns, S. (2008). Educational effects of the Tools of the Mind curriculum: A randomized trial. Early childhood research quarterly, 23(3), 299-313.

Biesta, G. (2009). Good education in an age of measurement: On the need to reconnect with the question of purpose in education. Educational Assessment, Evaluation and Accountability (formerly: Journal of Personnel Evaluation in Education), 21(1), 33-46.

Darling-Hammond, L., \& Bransford, J. (2007). Preparing teachers for a changing world: What teachers should learn and be able to do. John Wiley \& Sons.

Lee, S. M., Burgeson, C. R., Fulton, J. E., \& Spain, C. G. (2007). Physical education and physical activity: results from the School Health Policies and Programs Study 2006. Journal of school health, 77(8), 435-463.

Lie, A. (2004). Memperaktikan Cooperatif Learning di Ruang ruang Kelas. Grasindo. Jakarta.

Lucas, T., Villegas, A. M., \& Freedson-Gonzalez, M. (2008). Linguistically responsive teacher education: Preparing classroom teachers to teach English language learners. Journal of Teacher Education, 59(4), 361-373.

Manoe, L. (2020). Modified Instructional Teaching Method. Journal La Edusci, 1(1), 7-11.

Motteram, G. (2013). Innovations in learning technologies for English language teaching. British Council.

National Research Council. (2012). Education for life and work: Developing transferable knowledge and skills in the 21st century. National Academies Press.

Pintó, R. (2005). Introducing curriculum innovations in science: Identifying teachers' transformations and the design of related teacher education. Science education, 89(1), 112.

Soukup, J. H., Wehmeyer, M. L., Bashinski, S. M., \& Bovaird, J. A. (2007). Classroom variables and access to the general curriculum for students with disabilities. Exceptional Children, 74(1), 101-120. 